dromos del carnaval. Cuando ya está madura la fiesta, el ambiente se sacude con el aire de los Papaques: el himno de asueto que resonara incesante en los tres o cuatro días y noches que la ciudad dedica por entero a la alegría.

Pegada a la costa hay una isla: el Crestón, donde mora el vigía, por el lado del puerto nuevo. Alrededor se azotan perennemente las olas; sobre su punta luce de noche la falsa estrella de un faro potente.

Por dentro la ciudad se divierte cada noche y trabaja cada día. Hombres y mujeres jóvenes van en grupos cantando o lanzando vivas. De mueras nada sabe la ciudad de alma limpia que no quiere la muerte, sino la vida. Si la ciudad tiene tristezas las disimula ese franco saludo que a diario se cambian el rico y el pobre y el fácil tuteo que nos vuelve a hermanar en Dios. Por los barrios más pobres hay rastro de diversión, y en el mercado, por las noches, comida popular y tertulia general. Las calles suavemente irregulares se distinguen más que por el nombre por la propia fisonomía y siente el viajero que cada puerta ofrenda una sorpresa. $\mathrm{Ni}$ las casas ni las gentes están hechas por patrón. La Iglesia principal tiene en el frente un hermoso manto de piedra y se alza como un concierto de alegres colores en irrupción. Así estalla también múltiple el color en las plantas de los jardines públicos. Mazatlán es español y castizo: Mazatlán, orgullo de México, danos el contagio de tu orgullo y de tu libertad. Que todo México fuese como un Mazatlán grande, pensé una vez. Y lo vuelvo a pensar. - J O S E V A S O N C L OS.

Exclusivo para Atenea en Chile.

\title{
La emoción y la vida moderna
}

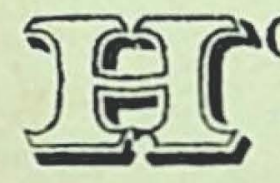

OY la vida no se comprende sino más allá de nosotros mismos. Esta rebusca de la emoción es el incentivo de todas las acciones del alma moderna, enferma de escepticismo que ya no cree ni siente esa felicidad tranquila predicada en otros tiempos. ¡Vivir para emocionarse van gritando los sentidos! Pero como la repetición del placer anula la sensación, la imaginación va agotándose a fuerza de ser hoy la mayor productora de energías. El ser humano no sabe qué es lo que desea, y extiende se- 
diento los labios hacia la lejana e inalcanzable fuente de la felicidad que la locura reviste bajo las más absurdas formas.

En una interesante conferencia que diera Gregorio Marañón, el ilustre médico español, le oí expresar el profundo desconsuelo que significa para los que se dedican a enriquecer la ciencia como factor de mejoramiento humano comprobar que, a pesar de haber concluido con muchos de los motivos que contribuían en mayor medida a la mortalidad, no se ha conseguido prolongar la vida ni concluir con sus miserias físicas, y, que en suma, la humanidad sigue su marcha doblada bajo el peso del dolor material, a pesar de todos sus esfuerzos para libertarse de él.

Y esto, porque a medida que concluyen las enfermedades infecciosas se aumentan las cerebrales: las afecciones nerviosas desde sus primeros estadios hasta las formas sistematizadas de la locura. Contó a modo de anécdota que recorriendo un gran hospital de Alemania, uno de los médicos le hacía ver el vacío de las salas destinadas treinta años atrás a las enfermedades microbianas, mientras le decía sentenciosamente: "Estas y todas las enfermerías se habilitarán para manicomios.»

Marañón cree que el ejercicio mental puro es prácticamente inofensivo para el cerebro humano, que nadie enferma de pensar demasiado, de investigar, de leer o de crear, por potente y continuado que sea el esfuerzo, siempre que se desarrolle en una atmósfera de paz emocional.

El cerebro del niño y el del joven es todavía sensible al trabajo mental puro, del que se defiende por el mecanismo automático de la distracción, pero el del adulto, bien entrenado, es capaz de una labor de estudio o de producción de increíble intensidad e inverosímilmente prolongada. Es en cambio la emoción, la ansiedad en la lucha por la vida, la angustia de los deseos no satisfechos, la que estira nuestros pobres nervios hasta quebrarlos. Como dice Marañón, estamos en pecado cronológico, hemos perdido el paso que iba rítmicamente con el tiempo y nos sentimos flotar en el vacío. Se vive desesperadarrente porque se sobrecargó el programa y porque se conoce la inutilidad del esfuerzo.... Se palpa la acción postiza de atiborrar las horas de agitaciones pequenitas. Nunca como ahora fueron los hombres más infelices en su falta de fe en causa grande alguna. Se llega a la fatiga, al agotamiento cerebral. Se siente el ansia del reposo, se obtiene, y el enfermo no sabe qué hacer de él, pues ya no son 
horas vacías las que necesita sino un ritmo de aquietamiento interior. Aun más, el correr del tiempo inactivo va haciéndose doloroso: la agitación es hoy una droga nociva pero necesaria.

En las grandes ciudades la emoción está aún al margen de los acontecimientos mismos: hay quienes no han acelerado el paso de la propia vida y que sienten, no obstante, la ansiosa predisposición. Ambiente que dejan los actos de los otros y que lleva al balance personal. Entra en acción el tamiz espiritual, la oposición a los hechos rutinarios y, ante el pobre resultado, sienten la violentá necesidad de recuperar la vida. Empiezan a mirar a cada ser que pasa como ese pobre niño del Pájaro Azul, que, separado antes de nacer de la elegida, buscaba ansioso en la frente de cada una el signo que le haría reconocer su felicidad aquí en la tierra. Pero ya los seres se han complicado y los gestos se pierden entre las multitudes. Quedan en la atmósfera, como ternura al viento, angustia o desesperación: incentivo que perciben los nervios agudizados de los supra-sensibles. Caminan espoleados por estas rachas grises que el aire trae. Los mil ruidos y visiones de la calle son sólo un eco en el sub-consciente del obsesionado. Y así desfilan los muy olvidados tras su pedacito de felicidad abstracta o humana.

Hay aún en las grandes ciudades la sugestión de los sitios y del pasado que inquieta el espíritu buscando la asimilación, y el espejismo de vibración con las distintas razas y los distintos hombres, extrayendo de cada cual su interés particular. El mundo sólo es hermoso como posibilidad de realizar, y la vida en el grado en que las acciones abren el camino de una real irrealidad.

París en su vida flotante es sólo un muestrario loco de la aspiración sin horizontes siderales. Los seres de todos los pueblos traen aquí su verbo particular, su herencia racial diferenciada, sus locuras o sus manías, dándole al diario vivir un sello de vuelta al mundo dentro de sus kilómetros cuadrados. Panorama de infinitos ventanales, suele también ofrecer cambios en sus distintas perspectivas. Y así, a veces, surge en el camino el solitario hombre de acero que mirando despectivamente el kaleidoscopio humano dice con gesto indiferente: "jParís no existe!», pues en él no está la clave que le permita su realización particular. Pero justamente París existe porque la realización íntima no está en ninguna parte. Cualquier punto del mundo en que se detenga el barco o el ferrocarril es igualmente hostil o extraño a la 
médula de nuestra psiquis, que tal vez castigada por algún dios cruel o vengativo fué condenada a ser la eterna solitaria, a quedarse en ese balbuceo de aproximación que le ofrecen las palabras, las artes o el amor. Y en esta conciencia trágica de soledad se tienden entonces los telones y las bambalinas, y a todos los sones de la orquesta rueda la vida de la gran ciudad.-M A R T A VER G A A.

\section{¿Hacia dónde va la poesía?}

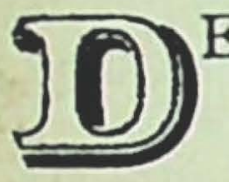

ESPUES de la guerra del 14 que desoló Europa y cuya repercusión económica llegó hasta los pueblos de Sudamérica, convirtiéndolos automáticamente en colonias del más poderoso pueblo que jamás registró la historia de la humanidad, el pensamiento, la sociología, el arte, no podían conservarse estacionarios, sino contexturarse de acuerdo con las urgentes necesidades contemporáneas. La mente del hombre, estática hasta entonces, se motoriza hacia radios de más campo de acción, donde solamente se agita un problema básico. La confusión, producto de la misma guerra, ensombreció un ciclo corto de la historia. Dentro del caotismo existente, no podía vislumbrarse un pensamiento analítico, creador y constructivo, sino un pensamiento y un arte cuyas células traían la negación de su ser.

La noche inmensa de la guerra no permitió que los hombres pudieran ver más allá del abismo. Los caminos de la vida estaban nitroglicerinados. El panorama europeo estaba encendido de locura, barajándose las ideas, tanto políticas como estéticas, dentro del más profundo y absoluto individualismo. El principio individualista en su aspecto clínico. Sólo después del año 17 en que alumbró una estrella la aurora de la hun:anidad, vemos la transformación material y espiritual por medio de las corrientes que determinan la evolución económica y social de la humanidad. Desde entonces los problemas no son de carácter privado, sino público. El individuo es un átomo de la gran maquinaria, célula de un cuerpo organizado que cumple su función. El mismo aindividualismo genial»-de que nos habla Cocteau-cumple su misión dentro de la sociedad, jamás fuera. Su aislamiento es su propia muerte. Por ejemplo, Francia fué un centro de experimenta- 